\title{
Recriticality Energetics of a Hypothetical Water Reflood Accident in a Damaged Light Water Reactor
}

\author{
K. N. Schwinkendorf
}

Date Published

April 1997

To Be Presented at ANS Annual Meeting Orlando, Florida June 1-5, 1997

Prepared for the U.S. Department of Energy Assistant Secretary for Environmental Management

Project Hanford Management Contractor for the

U.S. Department of Energy under Contract DE-ACO6-96RL13200

Copyright Licenes By accoptence of this article, the publisher and/or recipient acknowledges the

U.S. Government's right to retain a nonexclusive, royalty-free license in end to any copyright covering this paper.

Approved for public release; distribution is unlimited 
LEGAL DISCLAMMER

This report was prepared as an account of work sponsored by an agency of the United States Government. Neither the United States Government nor any agency thereof, nor any of their employees, nor any of their contractors, subcontractors or their employees, makes any warranty, express or implied, or assumes any legal liability or responsibility for the accuracy, completeness, or any third party's use or the results of such use of any information, apparatus, product, or process disclosed, or represents that its use would not infringe privately owned rights. Reference herein to any specific commercial product, process, or senvice by trade name. trademark, manufacturer, or otherwise, does not necessarily constitute or imply its endorsement, recommendation, or favoring by the United States Government or any agency thereof or its contractors or subcontractors. The views and opinions of authors expressed herein do not necessarily state or reflect those of the United States Government or any agency thereof.

This report has been reproduced from the best available copy.

Printed in the United States of Americe

DISCLM-2.CHP (1-91) 


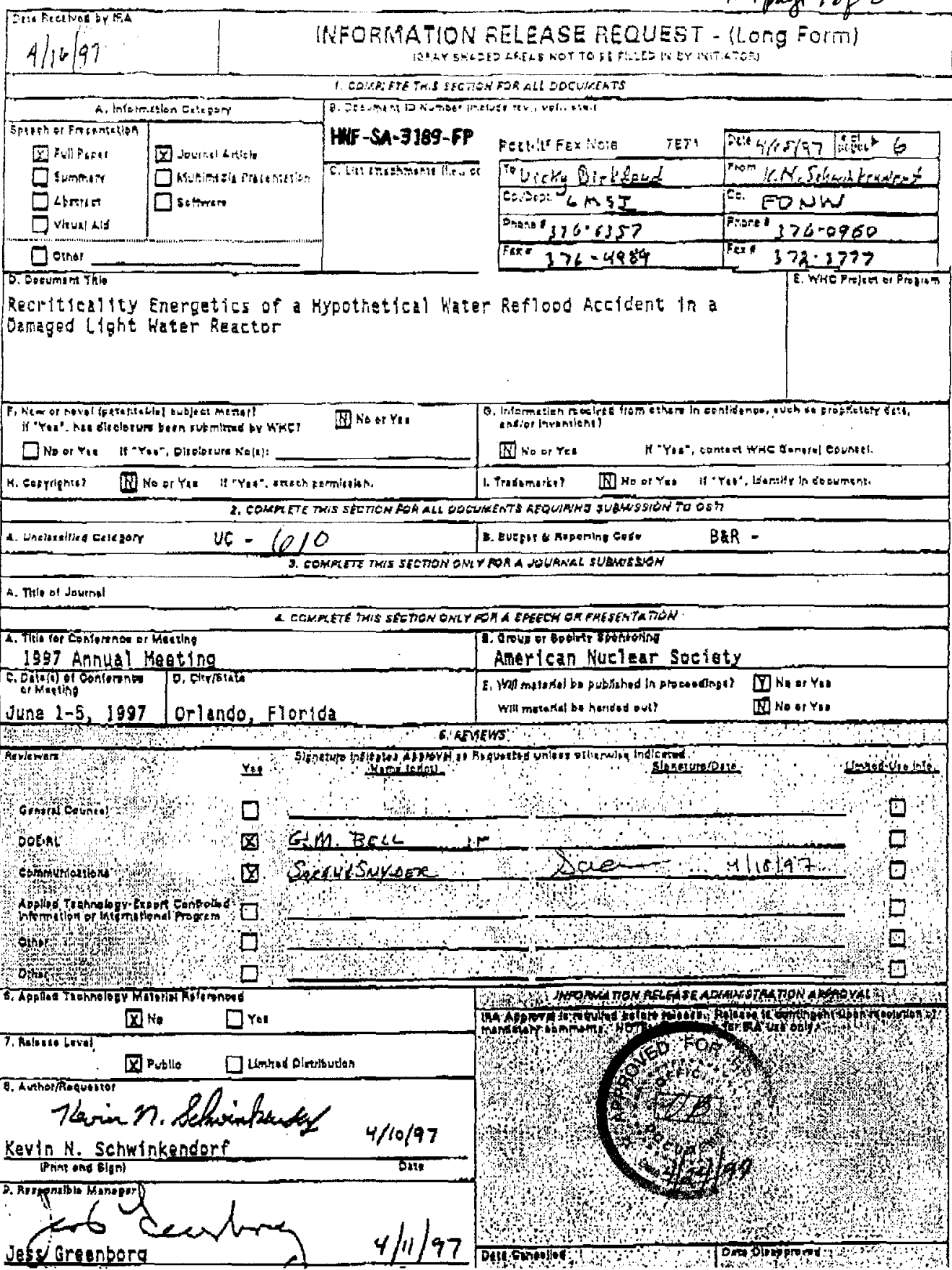




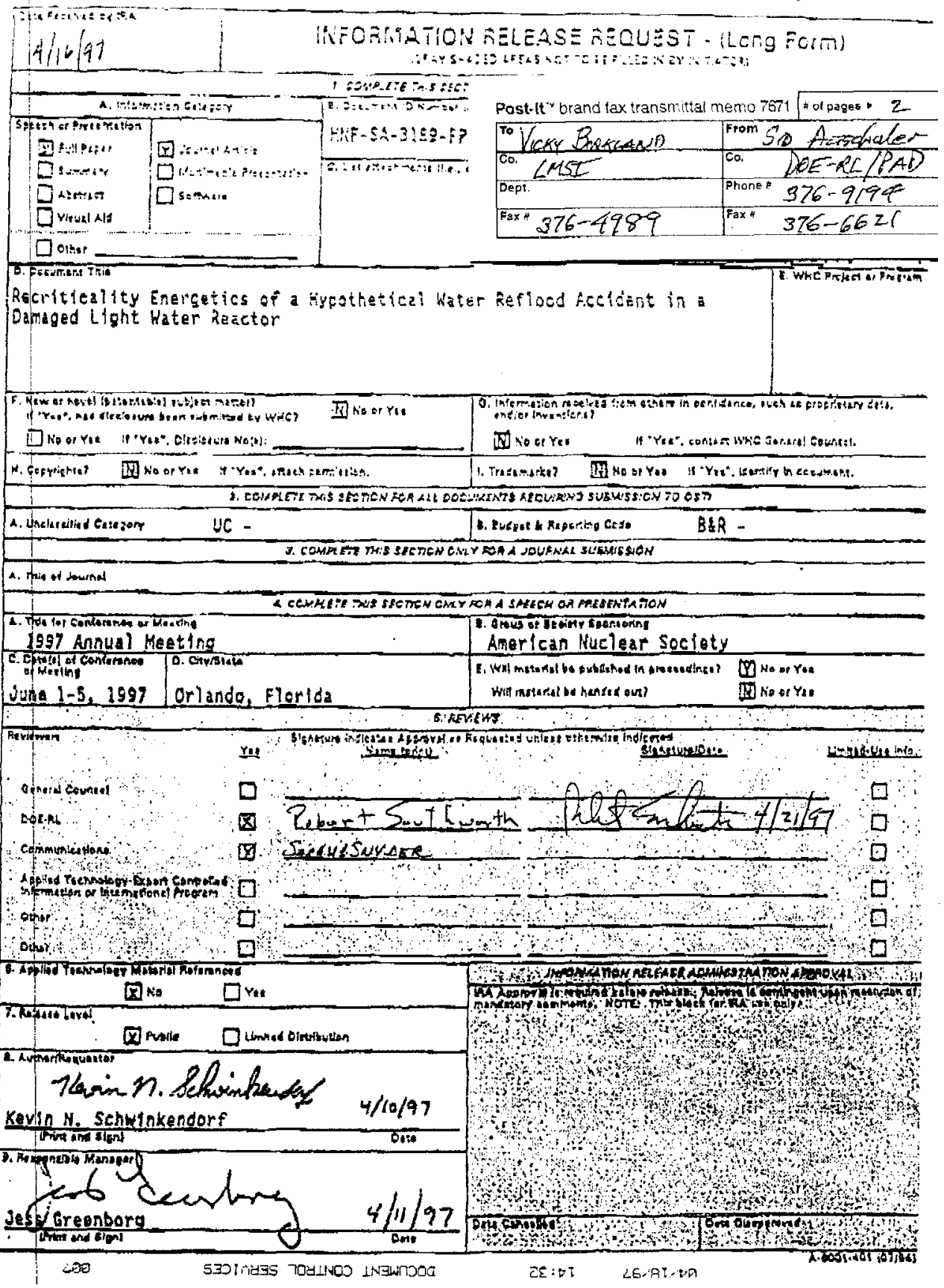


10. LEGENDSNOTICES/MARKINGS (Required by WHC-CM-3-4 or Reviewer). Feviewet hulicstes "pplicable markitigs to be af fixed or removed.

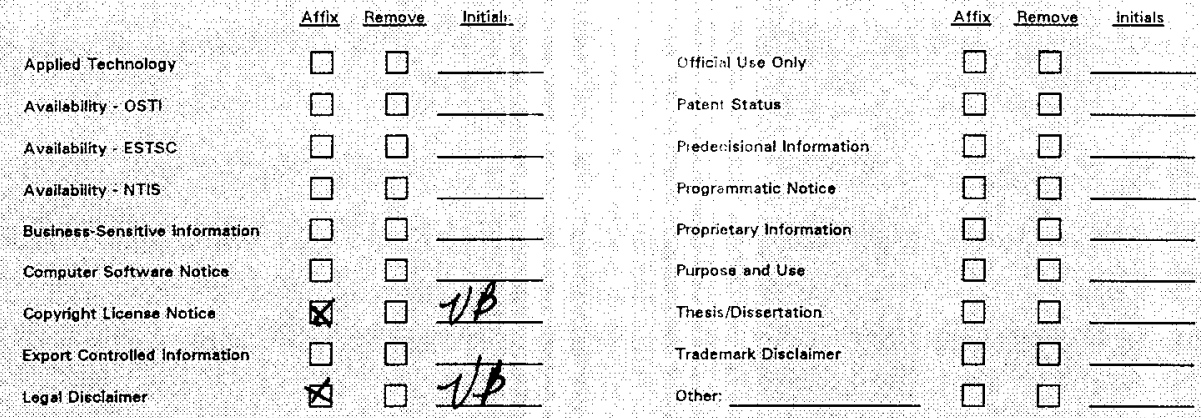

Umitod Disctosuro

IY MANDATORY COMMENTS I LST only mand atony comment's here All other comments shall be mede on the tocument and returned

to othe suthots

Reviewer [Print \& Sian] 


\title{
RECRITICALITY ENERGETICS OF A HYPOTHETICAL WATER REFLOOD ACCIDENT IN A DAMAGED LIGHT WATER REACTOR
}

\author{
K. N. Schwinkendorf \\ Fluor Daniel Northwest \\ P. O. Box 1050 \\ Richland, WA 99352-1050 \\ 1 (509) 376-0960
}

\section{INTRODUCTION}

The Three Mile Island (TMI-2) accident in 1979 resulted in approximately $45 \%$ of the fuel collapsing into an irregularly-shaped debris bed near the center of the core, while some of the molten material flowed into the lower dome of the reactor vessel where it solidified. ${ }^{1,2,3}$ The immediate cause of this severely degraded geometry was loss of coolant and subsequent heatup of the fuel from decay heat. The neutron chain reaction had shut down prior to fuel relocation (below $5 \mathrm{wt} \%{ }^{235} \mathrm{U}$ enrichment, fast-spectrum criticality is impossible). After the system had cooled sufficiently to allow for reintroduction of water, the core was reflooded to remove remaining decay heat; to ensure stable shutdown, the reflood water was heavily borated (in excess of $3000 \mathrm{ppm})$.

One scenario considered was the potential for increased nuclear reactivity of the debris bed with the reintroduction of water. This was guarded against by the operators using heavily borated reflood water. If the reflood water is insufficiently borated, and the system goes recritical during reflood, it is important to estimate the energy release. Is the event minor (reactor containment survives), or is the event major (such as the Chernobyl accident)? 


\section{ANALYSIS}

This accident was analyzed in a doctoral dissertation at the University of Washington. ${ }^{4}$ A two-dimensional $(\mathrm{r}, \mathrm{z})$ computer code was created, which was used to perform a parametric study to estimate the energy release, subject to several input variables, including water reflood rate and initial core temperature. This simulator, ATHENA_2D (for A Transient History for Energetic Nuclear Accidents), models multi-group neutron kinetics, coupled to computational fluid dynamics (CFD). The CFD heat source is derived from fission energy deposited in the fuel and then convected into the water, evaluated using multichannel thermal hydraulics.

Three possibilities were thought to exist for ultimate shutdown, depending upon the timing of nuclear dynamics and thermal energy transported into the water. If the transient is slow enough, boil-out of the water in that part of the core experiencing peak power (which tends to be the debris bed, because of its higher reactivity) will occur before the fuel remelts. Vigorous boiling introduces strong negative feedback and shuts down the nuclear transient. If the transient proceeds faster, fuel remelt might occur before boil-out of the peak power region. Fuel remelt would result in further relocation of debris, and a potential subsequent steam-explosion (and violent disassembly). Some time is required for the molten fuel to slump and mix with the water If the transient proceeds even faster, and the fuel vaporizes before slumping into the water, this could be even more violent. The fuel would undergo vapor-phase disassembly, and the steam explosion would still follow. 


\section{RESULTS}

ATHENA_2D simulations suggest that this accident will proceed according to the first scenario. In a thermal spectrum, nuclear dynamics are slow enough such that sufficient heat transfer occurs to boil the moderator before the fuel remelts. This generalization is asserted for oxide fuels, where melting temperatures are high; metal fuels were not analyzed, and their melting temperatures are lower. If the debris bed is small (if the rising water completely covers the more reactive debris bed before the water boils), this will tend to mitigate the nuclear transient; the positive reactivity insertion has ended. Local boiling effectively shuts down the nuclear transient. The effect may be initially local, but spreads rapidly, and small scale space-time power oscillations occurring immediately after initial shutdown are possible, presumably caused by chaotic void feedback effects from boiling.

Ninety transients were computed, and a range of energy releases was obtained, typically 5-7 GJ thermal energy. The power history for one such transient is shown in Figure 1, computed in both two and four neutron energy groups. Mechanical work (potential to directly produce further physical damage) was not evaluated, but previous work in core disruptive accident analysis suggests that the thermal-to-work energy conversion is not very efficient, and is generally in the neighborhood of $1-2 \%$. The highest energy release obtained just exceeded $10 \mathrm{GJ}$. Even if all of this thermal energy eventually formed water vapor (through long-term cooling), and was released into containment, the over-pressure would be insufficient to breach the containment building. This study was not an attempt to rigorously model, in precise geometric detail, the actual TMI-2 debris bed, but instead modeled azimuthally symmetric debris beds qualitatively similar to the TMI-2 end-state. 
This study concludes that even had TMI-2 experienced a thermal recriticality during water reflood of its highly damaged core, the event would not have breached containment.

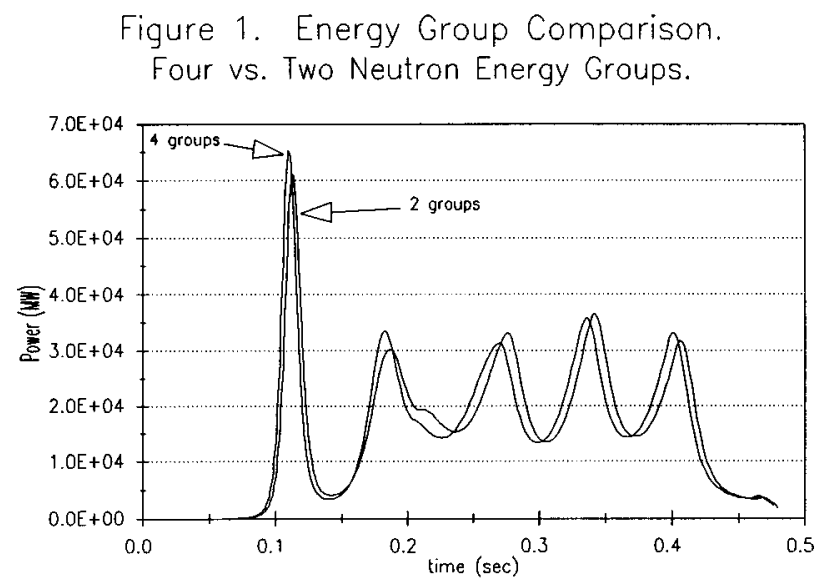

\section{REFERENCES:}

1. A Scenario of the TMI-2 Accident, J. M. Broughton, E. L. Tolman, P. Kuan, and D. A. Petti, ANS Trans., Vol. 57, October-November 1988, INEL, EG\&G Idaho.

2. TMI-2 Core-Bore Metallurgical and Fission Product Examination Results, R. K. McCardell, D. W. Aker, and C. S. Olsen, ANS Trans., Vol. 56, June 1988, INEL, EG\&G Idaho.

3. Materials Interactions and Temperatures in the TMI-2 Core, C. S. Olsen, S. M. Jensen, E. R. Carlson, B. A. Cook, ANS Trans., Vol. 57, October-November 1988, INEL, EG\&G Idaho.

4. Nuclear Energetics Analysis of Light Water Reactor Recriticality Under Severe Core Accident Conditions, K. N. Schwinkendorf, doctoral dissertation, University of Washington, 1996. 